\title{
Superficial corneal dystrophy
}

INSERM

\section{Source}

INSERM. (1999). Orphanet: an online rare disease and orphan drug data base. Superficial corneal dystrophy. ORPHA:98625

The superficial corneal dystrophies refer to a group of rare genetically determined corneal dystrophies (CDs) characterized by lesions affecting the corneal epithelium and its basement membrane and the superficial corneal stroma, and variable effects on vision depending on the type of dystrophy. 